\title{
SURVEY OF THE CONSUMER ATTITUDE OF TOURISTS VISITING SOUTH TRANSDANUBIA, HUNGARY
}

\author{
Bence ZÁVODI* \\ University of Pécs, Faculty of Sciences, Institute of Geography and Earth Sciences, Department of Tourism, Pécs, Hungary, e-mail: bence.zavodi@gmail.com \\ Géza SZABó \\ University of Pécs, Faculty of Sciences, Institute of Geography and Earth Sciences, Department of Tourism, Pécs, Hungary, e-mail: fg4t@gamma.ttk.pte.hu
}

\author{
Levente B. ALPEK
}

University of Pécs, Faculty of Sciences, Institute of Geography and Earth Sciences, Department of

Human Geography and Urban Studies, Pécs, Hungary, e-mail: alpeklevente @ gamma.ttk.pte.hu

\begin{abstract}
Citation: Závodi, B., Szabó, G., \& Alpek, L.B. (2021). SURVEY OF THE CONSUMER ATTITUDE OF TOURISTS VISITING SOUTH TRANSDANUBIA, HUNGARY. GeoJournal of Tourism and Geosites, 34(1), 245-250. https://doi.org/10.30892/gtg.34133-644
\end{abstract}

\begin{abstract}
The primary goal of the survey conducted was to work out adequate methods for the exploration of the consumer attitudes of tourists visiting South Transdanubia (Hungary) and to typify these attitudes, especially to analyse tourists' behaviour concerning local products. The source of the primary findings of the paper is a guest questionnaire survey conducted in 2018. These data were analysed - relying on professional literature - by cluster analysis and factor analysis. During the research comprehensive information was gained about the typical consumer habits of tourists arriving at South Transdanubia, which habits show several similarities and matches to consumer trends revealed by the literature research. Getting to know these consumer attitudes allowed the authors to create consumer types with the help of which the structure and size of the potential consumer base can be known.
\end{abstract}

Key words: rural tourism, consumer attitude, consumer type, local product, South Transdanubia, Hungary

\section{INTRODUCTION}

Tourism in Hungary is diverse, with several tourism products in the supply that attract both domestic and international guests. As regards the - regional distribution of the - number of guest nights spent in commercial accommodations in Hungary, two junctions are visible, Budapest and the Balaton region (19\%) by the figures of 2019 databases of guest numbers. On the other hand, the region in the focus of the paper has significantly lower indices, based on the guest nights spent in commercial accommodations it is only $4 \%$ of the volume of tourism in Hungary (1.261 million guest nights) that was realised in South Transdanubia (Hungarian Central Statistical Office, 2019). These statistical indices reflect the distribution of tourists before the pandemic. In the recent years, tourism in the region has gone through considerable changes, making researches on the tourism development of South Transdanubia important, also, the willingness to utilise these research findings in practice may be high. Rural areas as complex regions have gone through a fundamental transition in the last decades. As a result of this transition, they are not only spaces of agriculture but also areas of recreation and entertainment, and in some cases, we can even talk about geographical space of tourism (Lane and Kastenholz, 2015). For tourists participating in rural tourism, it is the quality of recreation, the opportunity to get away from the everyday stress of urban life that matters, as does the chance to get to know traditional lifestyles, authenticity, personal guest-host relationships and the proximity of nature (Frochot, 2005; Lane, 2009; Sidali et al., 2018; Sims, 2009). Approaching the issue from the demand side, a visible trend is the growing demand of urban dwellers to visit and get to know rural spaces (Bel et al., 2015; Molera and Abaladejo, 2007; Park et al., 2012; Pesonen, 2015; Sidali and Schulz, 2010). Rural areas thus have several advantages, as areas abundant in natural and cultural values and resources, offering a huge diversity of experiences where tourists can find the services that best match their needs (Campón-Cerro et al., 2017).

\section{LITERATURE REVIEW}

Results of empirical researches show that tourists visiting rural destinations do not only have different motivations but also different profiles, their behaviour and consumption habits are diverse and different (Eusébio et al., 2017; Fernández-Hernández et al., 2016; Molera and Albaladejo, 2007; Park et al., 2012; Pesonen, 2015). Knowing these attitudes may help manage the demand for destinations and the selection of the ideal segments (Kastenholz, 2004). Besides, effective marketing activity, which can be implemented in several ways, plays an important role. It can be product-centred (Frochot, 2005), can be based on activities pursued during travels (Eusébio et al., 2017; Pesonen, 2015), or connected to factors related to sustainability (Kastenholz et al., 2018). Tourism may play an important role in the sustainable development of rural areas especially in well organised and managed rural areas and regions where tourism appears as a part of the development strategy (Çakır et al., 2018; Clarke, 2005; Kastenholz, 2004; Kastenholz et al., 2012; Saxena et al., 2007).

The relationship between gastronomy and tourism has been appreciated over recent years (Cohen and Avieli, 2004; Long, 2004; Torres, 2002). The food offered to tourists may have a dominant impact on the economy, culture and environmental sustainability of the touristic destinations. Experts emphasise that locally produced goods have advantages both for the local inhabitants and the tourists (Boniface and Ioannides, 2017; Ilbery et al., 2003; Kim et al., 2009; Woodland and Acott, 2007). Local food products and the industries built on them (foods and beverages alike) are suitable for the improvement of sustainability both on the side of tourism and local community by the propaganda of sustainable farming solutions, the support of local businesses and creating a brand for the destination which is suitable for the attraction of even more tourists and investments. These advantages can also be seen concerning locals and tourists (Clark and Chabrel, 2007; Ilbery et al., 2003). Another achievement of initiatives based on local products can be linking visitors to local products and their producers. Telling the "story" of the food may satisfy tourists' need for authenticity, which may lead to the stabilisation of the market of these products (Sims, 2009). Tourists often search for the experience of authenticity and the typical and iconic products of the respective areas, in which local products may play an important role (Sims, 2009). Advantages attributed to "local" products - for example, better environment,

\footnotetext{
* Corresponding author
} 
healthier foods, greater social justice - can often be contradictory. The primary reason for this is the alternative meanings of "local" as a concept (Maye et al., 2007). When purchasing local products, it must be mentioned that tourists can experience a sort of moral satisfaction, as they choose a more ethical form of eating. The personal experience of eating and shopping can strengthen tourists' attachment to the destinations (Soper, 2007). Several studies have already proved that customers are willing to pay more for premium quality goods produced locally (Balogh et al., 2016; Carpio and Isengildina-Massa, 2008; Darby et al., 2006). According to Sims (2010), several consumers have been alienated from today's modern food industry. Their needs for natural and healthy foods may be prime motivating factors by which tourists can be attracted to rural areas. Tourists are also consumers in the destination who partly bring their consumption habits with them and partly show an interest in the local specialities that are novel for them, which means that local food products can appear as attractions to them. A visible trend has unfurled in food consumption since the traditional community attitude of the1960s through the individualist, "calculating" attitude of the 1980s and the followers of the trend of "uniqueness", modernity and hedonism in the 1990s to the "responsible" consumer attitude, representing ethics and fairness and respecting the community again, after the turn of the millennium (Dagevos and Gaasbeek, 2001; Lehota, 2004). By the early $21^{\text {st }}$ century, new concepts and behaviours are strongly attached to the consumption of foods like experience, already well-known in tourism, and lifestyle determining one's self-expression (Töröcsik, 2014). Besides this, the issues of environment and responsibility are becoming more and more important in influencing consumption attitude. The growth of the membership of the LOHAS (Lifestyles of Health and Sustainability) group, i.e. health- and environment-minded consumers indicates the growing role of responsibility taken for the narrower and broader environment (Wenzel et al., 2007). Consumption of foods produced in the direct vicinity of the place of residence, i.e. local food trend seems to be evaluated (Töröcsik, 2011), which appreciates authentic products of the region and also their producers, marking a return to the seasonal trend of food consumptions based on traditions (Smith and Mackinnon, 2008).

The primary objective of the examinations made was the elaboration of adequate methods for the exploration of the consumption attitude of tourists visiting South Transdanubia and the typifying of these attitudes, to allow the analysis of their behaviour concerning local products.

\section{MATERIALS AND METHODS}

The main source for the research findings of this paper is a questionnaire guest survey conducted in 2018. Sampling lasted from early summer in 2018 (May-June) right to the beginning of autumn (September-October), matching the seasonality of the region, i.e. sampling was done in pre-main- and after-season as well. Areas concerned by the questionnaire survey are within the territory of the touristic region of South Transdanubia. The selection of the settlements involved in the survey was done by a tourism index defined by the Hungarian Central Statistical Office, the number of guest nights spent in commercial accommodations. Results of the questionnaire survey were recorded in a database with the assistance of the Microsoft Excel software. Of the total sample $(n=430)$, only a certain proportion ( $n=166)$ could be included in further examinations, the main reason for which is the lack of data at certain variables.

This database was the foundation of the statistical methods applied in the subsequent phases of the research. The statistical methods were applied with the assistance of the software IBM SPSS Statistics 25.0. During the research, a total of 41 variables along 5 relevant dimensions were included in the factor analysis, as a result of which the total of the sample could be characterised with the use of 13 factors. Before the factor analysis, it was checked whether the variables chosen were suitable for further analyses. Table 1 shows the values achieved by the preliminary examinations proving the applicability of factor analysis, in the case of Bartlett-test, and also for the Kaiser-Meyer-Olkin indices. These tests proved that the sample is suitable for further analyses in terms of every dimension.

Table 1. Preliminary examinations proving the applicability of the analysis (Data source: own research)

\begin{tabular}{|l|c|c|c|c|c|c|}
\hline \multicolumn{2}{|c|}{$\begin{array}{c}\text { KMO and } \\
\text { Bartlett's Test }\end{array}$} & $\begin{array}{c}\text { Dimension } \\
\text { I }\end{array}$ & $\begin{array}{c}\text { Dimension } \\
\text { II }\end{array}$ & $\begin{array}{c}\text { Dimension } \\
\text { III }\end{array}$ & $\begin{array}{c}\text { Dimension } \\
\text { IV }\end{array}$ & $\begin{array}{c}\text { Dimension } \\
\text { V }\end{array}$ \\
\hline \multicolumn{2}{|c|}{ KMO } & 0.682 & 0.769 & 0.709 & 0.724 & 0.673 \\
\hline \multirow{2}{*}{$\begin{array}{l}\text { Bartlett's } \\
\text { Test }\end{array}$} & $\chi^{2}$ & 438.123 & 693.039 & 324.180 & 456.427 & 1064.124 \\
\cline { 2 - 7 } & df & 36 & 36 & 15 & 28 & 28 \\
\cline { 2 - 7 } & Sig. & 0.000 & 0.000 & 0.000 & 0.000 & 0.000 \\
\hline
\end{tabular}
correlations among the background variables (comparison of cluster centroids and averages) were done by variance analysis. During the survey of consumer types and local products, respondents could define on a scale from 1 to 5 to what extent they preferred local products. Aggregations were made for easier comprehensibility and easier analysability. Preference levels 1 and 2 were aggregated and given the specification typically not preferred. Preference level 3 was considered as neutral, while preference levels 4 and 5 were taken as category typically preferred. The main

Table 2. General demographic features of tourists involved in the survey (Data source: own research)

Gender: male: $61 \%$; female: $39 \%$

Age: under 18: 1\%; 18-25:30\%; 26-35: 27\%; 36-45: 14\%; 46-55: 18\%; 56-65: 4\%; above 65: 5\%

Marital status: single: $39 \%$; (married) couples with child(ren): $34 \%$; (married) couples with no child yet: $28 \%$

Schooling: elementary: 6\%; secondary: 50\%; higher level: $44 \%$

Income: less than HUF 100,000: 31\%; HUF 100,001-250,000: 48\%; above HUF 250,000: $21 \%$

\section{RESULTS AND DISCUSSION}

\section{Consumer attitude in the tourism of South Transdanubia}

Exploration of consumer attitudes was done along five dimensions (Figure 1). At the decision on the use of each dimension, it was an important principle of selection that they should be relevant in tourism research and match the research objective defined earlier.

Based on the nature of the respective dimensions, the variables were chosen from among the questions of the questionnaire, the main aspect in their selection was the connection between the - contents of the - dimension and the variable. The questions selected, i.e. the variables describing the different characteristic features of consumer behaviour have high touristic relevance, also supported by the literature. The result of the factor analysis aiming at the filtering of the variables is shown in Figure 1, demonstrating that it is 13 fact ors that describe the consumer preferences connected to the realised demand. For the sake of easier interpretation, we have highlighted the factor weights in the tables summarizing the relationship between the variables and dimensions (Table 3, 4, 5, 6, 7), so that the characteristic of the variable of each consumer attitude is outlined. Dimension I (Table 3) is the frequency of the use of traditional sources of information, in connection with which a total of nine variables were included for three consumer attitudes. The first attitude (expert information) is typical mainly of those tourists who prefer information mediated by the tourism trade. The information acquisition habits of tourists showing the signs of the 
second attitude (simplified information) reveal a preference for simple solutions primarily. A different attitude is shown by those tourists who prefer first-hand information; this factor contains variables representing the highest level of trust.

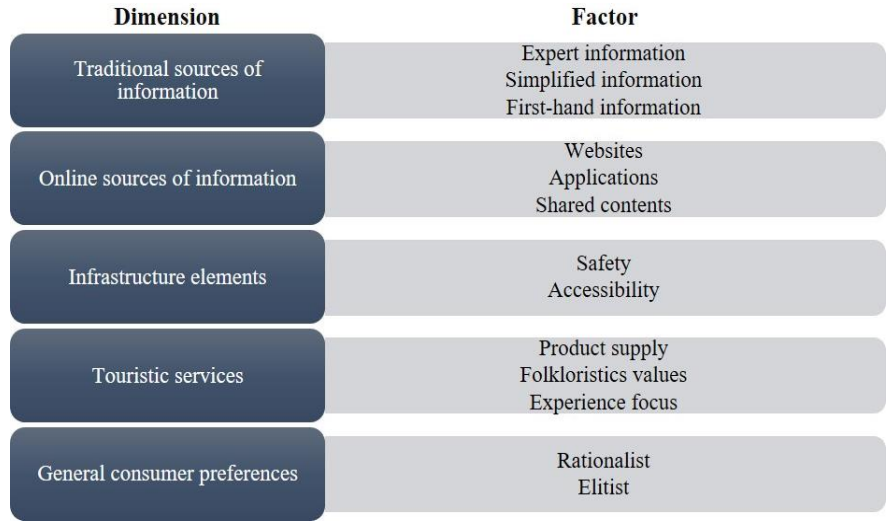

Figure 1. Survey dimensions applied and factors detected in the research

\begin{tabular}{|c|c|c|c|c|}
\hline Factor & Traditional sources of information & F1 & F2 & F3 \\
\hline \multirow{4}{*}{$\begin{array}{l}\text { F1 (Expert } \\
\text { information) }\end{array}$} & TourInform office (Frías et al., 2008) & 0.816 & -0.011 & 0.01 \\
\hline & Travel agency (Frías et al., 2008) & 0.76 & -0.037 & 0.005 \\
\hline & \begin{tabular}{|l|} 
Travel book \\
(Lyons and Wearing, 2008)
\end{tabular} & 0.728 & 0.114 & -0.026 \\
\hline & Travel fair (Sarmento et al. 2015) & 0.612 & 0.303 & 0.001 \\
\hline \multirow{3}{*}{$\begin{array}{l}\text { F2 (Simplified } \\
\text { information) }\end{array}$} & $\begin{array}{l}\text { Information signs, signs assisting } \\
\text { Orientation (Marschall et al., 2017) } \\
\end{array}$ & -0.163 & 0.679 & -0.085 \\
\hline & TV advertisement (Pan et al., 2011) & 0.314 & 0.663 & 0.184 \\
\hline & Flier, brochure (Berger, 2004) & 0.152 & 0.656 & 0.065 \\
\hline \multirow{2}{*}{$\begin{array}{l}\text { F3 (First-hand } \\
\text { information) }\end{array}$} & $\begin{array}{l}\text { Recommendation by relatives and } \\
\text { friends (Bieger and Lasser, 2004) }\end{array}$ & -0.01 & 0.117 & 0.8 \\
\hline & \begin{tabular}{|l} 
Previous experience \\
(Murphy et al., 2007)
\end{tabular} & -0.012 & -0.023 & 0.831 \\
\hline
\end{tabular}

Dimension II (Table 4) shows the frequency of the use of online sources of information, based on which three consumer attitudes were specified. The first attitude (websites) is true of those tourists who prefer websites from among all online sources of information. Attitude relying on applications primarily means reliance on opportunities offered by smartphones and different phone applications. Variables in the third attitude are typical of those tourists who rely on a specific segment of modern solutions, shared contents. Dimension III (Table 5) means the importance of the infrastructure elements of the destination.

Two consumer attitudes were here defined, both with 3 variables. The first attitude (security) is typical of those tourists mainly who pay great attention to factors listed among the security factors of a destination. Accessibility is considered as important by those tourists for whom access to the destination and movements within it are of utmost significance. Dimension IV (Table 6) is the importance of the elements related to the touristic services of the destination; three consumer attitudes (with the assistance of nine variables) were defined here. Shopping and related supply available in the destination is featured in the attitude called product supply. The second attitude (folkloristic values) is typical, in the first place, of tourists open to folk values, for whom the use of environment-friendly solutions is a decisive factor. The attitude of experience focus is characteristic for those tourists who attribute special importance to experiences coming from the services used. Dimension V (Table 7) is general consumer preferences, along which two consumer attitudes, with 4 variables each, assist the interpretation of the sample. Rationalist attitude is typical of those tourists in the first place who make their decisions by rational consumer preferences primarily. The elitist factor characterises those tourists whose decisions are influenced by special aspects.

\begin{tabular}{|c|c|c|c|c|}
\hline Factor & Touristic services & F1 & F2 & F3 \\
\hline \multirow{3}{*}{$\begin{array}{c}\text { F1 } \\
\text { (Product } \\
\text { supply) }\end{array}$} & $\begin{array}{l}\text { Supply of other local products in the region } \\
\text { (Kastenholz et al., 2016) }\end{array}$ & 0,812 & 0,284 & $-0,007$ \\
\hline & $\begin{array}{l}\text { Shopping facilities, commercial establishments } \\
\text { (Meng and Xu, 2012) }\end{array}$ & 0,754 & $-0,116$ & 0,311 \\
\hline & $\begin{array}{l}\text { Supply of local food products in the region } \\
\text { (Komariah et al., 2020) }\end{array}$ & 0,739 & 0,321 & 0,102 \\
\hline \multirow{3}{*}{$\begin{array}{c}\text { F2 } \\
\text { (Folkloristic } \\
\text { values) }\end{array}$} & $\begin{array}{l}\text { Demonstration of folk values, related programmes } \\
\text { (Rodzi et al., 2013) }\end{array}$ & 0,173 & 0,812 & 0,012 \\
\hline & $\begin{array}{l}\text { Use of environment friendly solutions } \\
\text { (Andereck, 2009) }\end{array}$ & $-0,024$ & 0,721 & 0,299 \\
\hline & Gastro- and other festivals, feasts (Timothy, 2015) & 0,263 & 0,716 & 0,11 \\
\hline \multirow{3}{*}{$\begin{array}{c}\mathbf{F 3} \\
\text { (Experience } \\
\text { focus) }\end{array}$} & $\begin{array}{l}\text { Quality of service, attitude of the staff } \\
\text { (Tsaur and Lin, 2004; Sharpley and Forster, 2003) }\end{array}$ & $-0,087$ & 0,154 & 0,755 \\
\hline & Hospitality of the locals (Mansour and Ariffin, 2016) & 0,18 & 0,108 & 0,714 \\
\hline & Having a community experience (Zou et al., 2012) & 0,26 & 0,074 & 0,566 \\
\hline
\end{tabular}

Table 6. Significance of the elements related to the touristic services

\begin{tabular}{|c|l|c|c|}
\hline Factor & General consumer preferences & F1 & F2 \\
\hline \multirow{5}{*}{$\begin{array}{c}\text { F1 } \\
\text { (Rationalist) }\end{array}$} & $\begin{array}{l}\text { Price and value ratio } \\
\text { (Mangion et al., 2005) }\end{array}$ & 0.757 & -0.016 \\
\cline { 2 - 4 } & Quality (Sánchez et al., 2006) & 0.749 & 0.036 \\
\cline { 2 - 5 } & $\begin{array}{l}\text { Price (Masiero and Nicolau, 2011) } \\
\text { Accessibility/availability } \\
\text { (Hashimoto and Telfer, 2006) }\end{array}$ & 0.749 & 0.033 \\
\cline { 2 - 4 } & Supply (Park and Jang, 2013) & 0.602 & 0.037 \\
\hline \multirow{5}{*}{ F2 (Elitist) } & $\begin{array}{l}\text { Fashionableness } \\
\text { (Turner and Witt, 2001) }\end{array}$ & 0.047 & 0.924 \\
\cline { 2 - 4 } & $\begin{array}{l}\text { "Luxury" character } \\
\text { (Thurlow and Jaworski, 2012) }\end{array}$ & 0.069 & 0.882 \\
\cline { 2 - 5 } & $\begin{array}{l}\text { Uniqueness } \\
\text { (Thurlow and Jaworski, 2012) }\end{array}$ & 0.06 & 0.671 \\
\hline \multicolumn{3}{|l|}{ Table 7. General consumer preferences } \\
\hline
\end{tabular}

(Data source: own research)

\section{Consumer types in the tourism of South Transdanubia}

Using the consumer attitudes defined, respondents involved in the survey were classified into five types by cluster analysis (Table 8). For the easier analysis of the table, we highlighted the consumer attitudes in terms of every consumer types in each dimension. The earlier presentation of consumer attitudes allows that variables have also become definable for each consumer type. 
The first type, making the largest part of the sample, is goal-oriented tourists, with $34 \%$ of tourists surveyed falling into this category. Of all 13 consumer attitudes, 7 are typical of them. During their travels they pay special attention to accessibility and product supply, also, they typically

\begin{tabular}{|c|c|c|c|c|c|c|}
\hline \multirow{3}{*}{ Dimension } & & \multicolumn{5}{|c|}{ Consumer type } \\
\hline & \multirow{2}{*}{$\begin{array}{c}\text { Consumer } \\
\text { attitude }\end{array}$} & Goal-oriented & Meticulous & Classical & Exclusive & Hedonist \\
\hline & & $34 \%$ & $20 \%$ & $20 \%$ & $14 \%$ & $11 \%$ \\
\hline \multirow{6}{*}{$\begin{array}{l}\text { Traditional } \\
\text { sources of } \\
\text { information }\end{array}$} & \multirow{2}{*}{$\begin{array}{c}\text { Expert } \\
\text { information }\end{array}$} & Atypical & Typical & Typical & Typical & Atypical \\
\hline & & $(-0.596)$ & $(0.296)$ & $(0.144)$ & $(\mathbf{1 . 4 0 0 )}$ & $(-0.359)$ \\
\hline & \multirow{2}{*}{\begin{tabular}{|c|}
$\begin{array}{c}\text { Simplified } \\
\text { information }\end{array}$ \\
\end{tabular}} & Typical & Typical & Atypical & Typical & Atypical \\
\hline & & & $(0.521)$ & $(-0.415)$ & $(0.093)$ & $(-0.475)$ \\
\hline & \multirow{2}{*}{$\begin{array}{l}\text { First-hand } \\
\text { information }\end{array}$} & & Typical & & Atypical & \\
\hline & & & $(0.394)$ & & & 25) \\
\hline \multirow{6}{*}{$\begin{array}{l}\text { Online sources } \\
\text { of information }\end{array}$} & \multirow{2}{*}{ Websites } & Aty & Typical & Typical & Typical & \\
\hline & & $(-0$ & $(0.935)$ & $(\mathbf{0 . 3 2 6 )}$ & $(0.340)$ & 86) \\
\hline & \multirow{2}{*}{ ppli } & & Typical & Typical & Typical & Atypical \\
\hline & & & $(0.812)$ & & & \\
\hline & \multirow{2}{*}{$\begin{array}{c}\text { Shared } \\
\text { contents }\end{array}$} & & & & & \\
\hline & & $(-0)$ & $(0.020)$ & $(-0)$ & (1.739) & $(-0.298)$ \\
\hline \multirow{4}{*}{$\begin{array}{c}\text { Infrastructure } \\
\text { elements }\end{array}$} & \multirow{2}{*}{ Securi } & & Typical & & Atypical & Atypical \\
\hline & & & $(\mathbf{0 . 4 5 8 )}$ & & $(-0.502)$ & $(-1.434)$ \\
\hline & \multirow{2}{*}{ Accessibility } & & & & & pical \\
\hline & & & (0) & & $(-0$ & 76) \\
\hline \multirow{6}{*}{$\begin{array}{l}\text { Touristic } \\
\text { services }\end{array}$} & \multirow{2}{*}{$\begin{array}{l}\text { Product } \\
\text { supply }\end{array}$} & Ty] & Typical & Atypical & Typical & Atypical \\
\hline & & $(0.2$ & $(0.572)$ & $(-0.814)$ & $(0.256)$ & $(-0.092)$ \\
\hline & \multirow{2}{*}{ Folk values } & Typical & Typical & Typical & Typical & Atypical \\
\hline & & & $(0.063)$ & & $(-0.073)$ & $(-1.314)$ \\
\hline & \multirow{2}{*}{$\begin{array}{l}\text { Experience- } \\
\text { focus }\end{array}$} & & & & & \\
\hline & & & $(\mathbf{0 . 5 8 2})$ & $(-0$. & $(-1.197)$ & 34) \\
\hline \multirow{4}{*}{$\begin{array}{c}\text { General } \\
\text { consumer } \\
\text { preferences }\end{array}$} & \multirow{2}{*}{ Rationalist } & & Typical & Aty & Atypical & Atypical \\
\hline & & $(0.396)$ & $(0.163)$ & $(-0.169)$ & $(-0.659)$ & $(-0.866)$ \\
\hline & \multirow{2}{*}{ Elitist } & Atypi & Typical & Atypical & Typical & Atypical \\
\hline & & $(0.018)$ & $(0.384)$ & $(-0.791)$ & $(0.862)$ & $(-0.001)$ \\
\hline
\end{tabular}

Table 8 . Consumer types defined by the cluster analysis (Data source: own research) show rationalist consumer preferences in the first place.

The second type shows almost all consumer attitudes, 12 out of the 13, which gave them the label of meticulous tourists. They make $20 \%$ of the total of the sample. Their information acquisition typically takes place by the application of websites, mobile phone apps and simplified information. Also, the pattern of their consumption habits is significantly influenced by experience -focus and the product supply. Tourists in the third category were defined as classical tourists, characterised by 6 consumer attitudes of the 13 defined. Members of this type make $20 \%$ of the sample. As regards the consumer attitudes most typical of them, these tourists make their travel and consumption decisions based on websites, applications and expert information.

The fourth category of the sample, by the consumer attitudes typifying them, can be called exclusive tourists. They make $14 \%$ of the sample. Of the 13 consumer attitudes defined, 8 are typical of them. The sources of their information are usually shared contents and expert information; also, they typically have an elitist consumer attitude.

The fifth type in the sample is a specific type, of the members of this type, called the hedonists, only 2 consumer attitudes of the 13 are typical. Travel-related information is obtained in this group from first-hand sources. It must be emphasised that experience-focus is of special importance for them when it comes to touristic services available in a destination.

\section{The positioning of the consumer types detected in the classifications in the literature}

The typifying of the consumers that we gained by our survey can be compared to further classifications in the professional literature. When analysing consumer trends, Lehota (2004) defined six consumer attitudes. The result of the cluster analysis done by Malota et al. (2018) also yielded six consumer types, in our terminology: consumer segments. The respective types, based on their characteristic features, can be connected in different ways to the consumer attitudes that our research detected. These connections of different quality are demonstrated in Table 9. The table shows whether there is a correlation between our consumer types and the consumer types defined in the literature, which were classified into four categories: correlation by their characteristic features, indirect correlation by their characteristic features, opposite types and no correlation. As regards the consumer types identified by this survey, it is the types "meticulous" and "goal-oriented" that can be best matched to the types demonstrated in the professional literature. The group of the "exclusive" is quite similar to those of the "unique" by Lehota (2004) and the "active perfectionists" and those "seeking local specialities" identified by Malota et al. (2018). Analogies to "hedonists" can be found in Lehota (2004) "individualists" and "unique". The characteristic features of "classical tourists" are the least similar to the types in the other two classification systems; in fact, the type "responsible" by Lehota (2004) even shows opposite features.

\begin{tabular}{|c|c|c|c|c|c|c|c|c|c|c|c|c|}
\hline \multirow[t]{2}{*}{ Our types } & \multicolumn{6}{|c|}{ Consumer types by Lehota (2004) } & \multicolumn{6}{|c|}{ Consumer segments by Malota et al. (2018) } \\
\hline & Individualist & Social & Traditionalist & Calculating & Unique & Responsible & $\begin{array}{c}\text { Active } \\
\text { perfectionists }\end{array}$ & $\begin{array}{c}\text { Seeking value } \\
\text { for money }\end{array}$ & $\begin{array}{c}\text { Seeking } \\
\text { local } \\
\text { specialities }\end{array}$ & $\begin{array}{c}\text { Everyday } \\
\text { active }\end{array}$ & $\begin{array}{c}\text { Price } \\
\text { sensitive }\end{array}$ & $\begin{array}{c}\text { Casual } \\
\text { perfectionists }\end{array}$ \\
\hline Goal-oriented & + & 0 & $=$ & $=$ & 0 & $\mathrm{x}$ & $=$ & + & 0 & 0 & + & + \\
\hline Meticulous & + & $=$ & 0 & $=$ & + & $=$ & + & $=$ & + & 0 & $=$ & $=$ \\
\hline Classical & $=$ & 0 & $=$ & $=$ & 0 & $\mathrm{x}$ & $=$ & $=$ & $=$ & $=$ & 0 & $=$ \\
\hline Exclusive & $=$ & 0 & $=$ & $\mathrm{x}$ & + & 0 & + & $=$ & + & 0 & $\mathrm{x}$ & $=$ \\
\hline Hedonist & + & 0 & 0 & $=$ & + & 0 & $=$ & 0 & $=$ & 0 & $\mathrm{x}$ & $=$ \\
\hline
\end{tabular}

Table 9. Relationship dimensions among the consumer types (Source: Lehota, 2004; Malota et al., 2018; own research)

Legend: Direct correlation by their characteristic features: +; Indirect correlation by their characteristic features: =; Opposite types: $\mathrm{x}$; No correlation: 0

It can be said about all consumer types identified in our research (Table 10) that the overwhelming majority of tourists fall into the category typically preferred when it comes to local products. It is seen that most tourists had average or above-average preference levels. One of the reasons for this may be the fact that the trends identified in the introductory part of the paper are also true for tourists travelling to South Transdanubia, their openness to and interest in local products is traceable also during their travels.

\begin{tabular}{|l|c|c|c|}
\hline & Typically not preferred & Neutral & Typically preferred \\
\hline Goal-oriented & $6 \%$ & $33 \%$ & $61 \%$ \\
\hline Meticulous & $4 \%$ & $18 \%$ & $79 \%$ \\
\hline Classical & $13 \%$ & $19 \%$ & $69 \%$ \\
\hline Exclusive & $11 \%$ & $17 \%$ & $72 \%$ \\
\hline Hedonist & $0 \%$ & $27 \%$ & $73 \%$ \\
\hline
\end{tabular}

Table 10. Distribution of the preference for local products among the consumer types (Data source: own research)

\section{CONCLUSION}

In our research, we gained a lot of diverse information about the consumption habits typical of tourists visiting South Transdanubia, which can be correlated and matched in several aspects to the consumer trends identified in the professional literature. Getting to know these consumer attitudes allowed us to create consumer types by which the structure and size of the potential consumer base can be learnt.

As regards the preference level of the respective consumer types for local product, the proportions within the types and the formerly identified consumer attitudes, the following statements can be made. Those types that were typified by more than one attitude concerning the 
sources of information had a neutral preference level in a smaller proportion. The types relying on expert information or websites or applications showed a smaller proportion of neutral preference level. As a summary, it can be stated that the regular use of different sources of information promotes the birth of preference for local products in both a positive and negative way.

Despite the lack of preference for folkloristic values, $73 \%$ of hedonist tourists are in the category of "typically preferred". The categories of which a hedonist attitude is less typical showed this low preference level in higher proportion. The categories characterised by the elitist attitude showed a neutral attitude in a lower proportion than other categories did. The categories not characterised by attitudes related to online sources of information showed a significantly higher level of neutral preference.

High level of preference is most characteristic for the meticulous type, a reason for which may be the fact that 12 out of the 13 attitudes are typical of them, i.e. their decisions made about local products is based on the consideration of several aspects. A high level of preference is less typical for the goal-oriented type, which may be explained by the fact that members of this group rely on simplified information, only.

A neutral preference level is most typical of the goal-oriented type, a reason for which may be their reliance of the members of this category on simplified sources of information, only. A neutral preference level is most typical of the exclusive type, which may be explained by the fact that this is the only category that relies on shared contents as a source of information.

A low preference level is most typical of the classical type; a reason for this may be the fact that hedonist attitude is not typical of them. A low preference level is least typical of the hedonist type, a reason for which might be the fact that only two attitudes are typical of them.

The future way of this research could be the search for the relationships between the touristic demand and the consumer types determined by our survey concerning the local products of the Southern Transdanubia. These results would be beneficial for the region itself and based on them tourism professionals would be able to create development strategies based on the current behaviour of the tourists.

\section{Acknowledgement}

This publication/research has been supported by the European Union and Hungary and co-financed by the European Social Fund through the project EFOP-3.6.2-16-2017-00017, titled "Sustainable, intelligent and inclusive regional and city models".

\section{REFERENCES}

Akay, B. (2020). Examining the Rural Tourism Experiences of Tourists in Emerging Rural Tourism Destination: Burdur Province, Turkey. GeoJournal of Tourism and Geosites, 29(2), 534-544. https://doi.org/10.30892/gtg.29212-487

Andereck, K.L. (2009). Tourists' perceptions of environmentally responsible innovations at tourism businesses. Journal of Sustainable Tourism, 17(4), 489499. https://doi.org/10.1080/09669580802495790

Anderson, C.M., Das, C., \& Tyrrell, T.J. (2006). Parking preferences among tourists in Newport, Rhode Island. Transportation Research Part A: Policy and Practice, 40(4), 334-353. https://doi.org/10.1016/j.tra.2005.06.005

Balogh, P., Békési, D., Gorton, M., Popp, J., \& Lengyel, P. (2016). Consumer willingness to pay for traditional food products. Food Policy, 61, 176-184. https://doi.org/10.1016/j.foodpol.2016.03.005

Bel, F., Lacroix, A., Lyser, S., Rambonilaza, T., \& Turpin, N. (2015). Domestic demand for tourism in rural areas: Insights from summer stays in three French regions. Tourism Management, 46, 562-570. https://doi.org/10.1016/j.tourman.2014.07.020

Berger, A.A. (2004). Deconstructing travel: Cultural perspectives on tourism. Walnut Creek, CA: Altamira Press.

Bieger, T., \& Laesser, C. (2004). Information Sources for Travel Decisions: Toward a Source Process Model. Journal of Travel Research, 42(4), 357-371. https://doi.org/10.1177/0047287504263030

Boniface, P., \& Ioannides, D. (2017). Tasting tourism: Travelling for food and drink. Abingdon: Routledge.

Buhalis, D., \& Michopoulou, E. (2011). Information-enabled tourism destination marketing: Addressing the accessibility market. Current Issues in Tourism, 14(2), 145-168. https://doi.org/10.1080/13683501003653361

Çakır, O., Evren, S., Tören, E., \& Kozak, N. (2018). Utilizing the Sustainable Livelihoods Approach to Evaluate Tourism Development from the Rural Host Communities' Point of View: The Case of Cappadocia (Turkey). GeoJournal of Tourism and Geosites, 21. 7-25.

Campón-Cerro, A.M., Hernández-Mogollón, J.M., \& Alves, H. (2017). Sustainable improvement of competitiveness in rural tourism destinations: The quest for tourist loyalty in Spain. Journal of Destination Marketing \& Management, 6(3), 252-266. https://doi.org/10.1016/j.jdmm.2016.04.005

Carpio, C.E., \& Isengildina-Massa, O. (2009). Consumer willingness to pay for locally grown products: The case of South Carolina. Agribusiness, 25(3), 412426. https://doi.org/10.1002/agr.20210

Clark, G., \& Chabrel, M. (2007). Measuring Integrated Rural Tourism. Tourism Geographies, 9(4), 371-386. https://doi.org/10.1080/14616680701647550

Clarke, J. (2005). Chapter 5. Effective Marketing for Rural Tourism. Rural Tourism and Sustainable Business, 87-102. https://doi.org/10.21832/9781845410131-008

Cohen, E., \& Avieli, N. (2004). Food in tourism. Annals of Tourism Research, 31(4), 755-778. https://doi.org/10.1016/j.annals.2004.02.003

Dagevos, J.C., \& Gaasbeek, A.F. (2001). Approaching Contemporary Food Consumers: A Few Reflections on Research and Results. 71.st. EAAE Seminar The Food Consumer in the Early 21.st. Century, 1-8.

Darby, K., Batte, M.T., Ernst, S., \& Roe, B. (2006). Willingness to pay for locally produced foods: A customer intercept study of direct market and grocery store shoppers. Selected Paper prepared for presentation at the American Agricultural Economics Association Annual Meeting, Long Beach, California. 1-30.

Eusébio C., Carneiro, M.J., Kastenholz, E., Figueiredo, E., \& Silva, D.S. (2017). Who is consuming the countryside? An activity-based segmentation analysis of the domestic rural tourism market in Portugal. Journal of Hospitality and Tourism Management, 31, 197-210. https://doi.org/10.1016/j.jhtm.2016.12.006

Fernández-Hernández, C., León, C.J., Aranã, J.E., \& Díaz-Pére, F. (2016). Market segmentation, activities and environmental behaviour in rural tourism. Tourism Economics, 22(5), 1033-1054.

Frochot, I. (2005). A benefit segmentation of tourists in rural areas: A Scottish perspective. Tourism Management, 26(3), 335-346. https://doi.org/10.1016/j. tourman.2003.11.016

Frías, D.M., Rodríguez, M.A., \& Castañeda, J.A. (2008). Internet vs. travel agencies on pre-visit destination image formation: An information processing view. Tourism Management, 29(1), 163-179. https://doi.org/10.1016/j.tourman.2007.02.020

Hashimoto, A., \& Telfer, D.J. (2006). Selling Canadian Culinary Tourism: Branding the Global and the Regional Product. Tourism Geographies, 8(1), 31-55. https://doi.org/10.1080/14616680500392465

Hsu, F., Lin, Y., \& Ho, T. (2012). Design and implementation of an intelligent recommendation system for tourist attractions: The integration of EBM model, Bayesian network and Google Maps. Expert Systems with Applications, 39(3), 3257-3264. https://doi.org/10.1016/j.eswa.2011.09.013

Ilbery, B., Kneafsey, M., Bowler, I., \& Clark, G. (2003). Quality products and services in the lagging rural regions of the European Union: a producer perspective. In K. Beesley, H. Millward, B. Ilbery, \& L. Harrington (Eds.). The new countryside: geographic perspectives on rural change, 126-142, Brandon University (Rural Development Institute), and Saint Mary's University.

Kastenholz, E. (2004). 'Management of Demand' as a Tool in Sustainable Tourist Destination Development. Journal of Sustainable Tourism, 12(5), 388-408. https://doi.org/10.1080/09669580408667246

Kastenholz, E., Carneiro, M.J., Marques, C.P., \& Lima, J. (2012). Understanding and managing the rural tourism experience - The case of a historical village in Portugal. Tourism Management Perspectives, 4, 207-214. https://doi.org/10.1016/j.tmp.2012.08.009

Kastenholz, E., Eusébio, C., \& Carneiro, M.J. (2016). Purchase of local products within the rural tourist experience context. Tourism Economics, 22(4), 729748. https://doi.org/10.1177/1354816616654245

Kastenholz, E., Eusébio, C., \& Carneiro, M.J. (2018). Segmenting the rural tourist market by sustainable travel behaviour: Insights from village visitors in Portugal. Journal of Destination Marketing \& Management, 10, 132-142. https://doi.org/10.1016/j.jdmm.2018.09.001

Kim, Y.G., Eves, A., \& Scarles, C. (2009). Building a model of local food consumption on trips and holidays: A grounded theory approach. International Journal of Hospitality Management, 28(3), 423-431. https://doi.org/10.1016/j.ijhm.2008.11.005

Komariah, K., Razzaq, A.R., Nugraheni, M., Lastariwati, B., \& Mahfud, T. (2020). The Antecedent Factor Of Tourists' Intention To Consume Traditional Food. GeoJournal of Tourism and Geosites, 32(4), 1209-1215. https://doi.org/10.30892/gtg.32403-559 
Lane, B. (2009). Rural Tourism: An Overview. The SAGE Handbook of Tourism Studies, 355-371. https://doi.org/10.4135/9780857021076.n20

Lane, B., \& Kastenholz, E. (2015). Rural tourism: The evolution of practice and research approaches - towards a new generation concept? Journal of Sustainable Tourism, 23(8-9), 1133-1156. https://doi.org/10.1080/09669582.2015.1083997

Lehota, J. (2004). Az élelmiszerfogyasztói magatartás hazai és nemzetközi trendjei. [Domestic and international trends in food consumer behaviour] Élelmiszer, táplálkozás és marketing, 1(1-2), 7-13.

Long, L.M. (2004). Culinary tourism. Kentucky: University Press of Kentucky.

Lyons, K.D., \& Wearing, S. (2008). Volunteer tourism as alternative tourism: Journeys beyond otherness. Journeys of Discovery in Volunteer Tourism: International Case Study Perspectives, 3-11. https://doi.org/10.1079/9781845933807.0003

Malota, E., Gyulavári, T., \& Bogáromi, E. (2018). Mutimiteszel: Élelmiszer vásárlási és fogyasztási preferenciák, étkezési szokások a magyar lakosság körében [Food purchasing and food consumption preferences and eating habits among Hungarian consumers]. In A hatékony marketing - EMOK 2018 Nemzetközi Tudományos Konferencia konferenciakötete, Selye János Egyetem, Komárom, 710-720.

Mangion, M., Durbarry, R., \& Sinclair, M.T. (2005). Tourism Competitiveness: Price and Quality. Tourism Economics, 11(1), 45-68. https://doi.org/ $10.5367 / 0000000053297202$

Mansour, J.S., \& Ariffin, A.A. (2016). The Effects of Local Hospitality, Commercial Hospitality and Experience Quality on Behavioral Intention in Cultural Heritage Tourism. Journal of Quality Assurance in Hospitality \& Tourism, 18(2), 149-172. https://doi.org/10.1080/1528008x.2016.1169474

Mariani, M.M., Mura, M., \& Felice, M.D. (2018). The determinants of Facebook social engagement for national tourism organizations' Facebook pages: A quantitative approach. Journal of Destination Marketing \& Management, 8, 312-325. https://doi.org/10.1016/j.jdmm.2017.06.003

Marschall, S., Granquist, S.M., \& Burns, G.L. (2017). Interpretation in wildlife tourism: Assessing the effectiveness of signage on visitor behaviour at a seal watching site in Iceland. Journal of Outdoor Recreation and Tourism, 17, 11-19. doi:10.1016/j.jort.2016.11.001

Masiero, L., \& Nicolau, J.L. (2011). Tourism Market Segmentation Based on Price Sensitivity. Journal of Travel Research, 51(4), 426-435. https://doi.org/10.1177/0047287511426339

Maurer, C., \& Hinterdorfer, B. (2013). The Adoption of Pinterest for Destination Marketing: The Case of Austrian Destinations. Information and Communication Technologies in Tourism 2014,213-225. https://doi.org/10.1007/978-3-319-03973-2_16

Maye, D., Holloway, L., \& Kneafsey, M. (2007). Alternative food geographies: Representation and practice. Amsterdam: Elsevier.

Meng, F., \& Xu, Y. (2012). Tourism shopping behavior: Planned, impulsive, or experiential? International Journal of Culture, Tourism and Hospitality Research, 6(3), 250-265. https://doi.org/10.1108/17506181211246401

Molera, L., \& Albaladejo, I.P. (2007). Profiling segments of tourists in rural areas of South-Eastern Spain. Tourism Management, 28(3), 757-767. https://doi.org/10.1016/j.tourman.2006.05.006

Mordue, T. (2017). New urban tourism and new urban citizenship: Researching the creation and management of postmodern urban public space. International Journal of Tourism Cities, 3(4), 399-405. https://doi.org/10.1108/ijtc-04-2017-0025

Murphy, L., Mascardo, G., \& Benckendorff, P. (2007). Exploring word-of-mouth influences on travel decisions: Friends and relatives vs. other travellers. International Journal of Consumer Studies, 31(5), 517-527. https://doi.org/10.1111/j.1470-6431.2007.00608.x

No, E., \& Kim, J.K. (2015). Comparing the attributes of online tourism information sources. Computers in Human Behavior, 50, 564-575. https://doi.org/10.1016/j.chb.2015.02.063

Pan, S., Tsai, H., \& Lee, J. (2011). Framing New Zealand: Understanding tourism TV commercials. Tourism Management, 32(3), 596-603. https://doi.org/10.1016/j.tourman.2010.05.009

Park, D., Lee, H., \& Yoon, Y. (2012). Understanding the Benefit Sought by Rural Tourists and Accommodation Preferences: A South Korea Case. International Journal of Tourism Research, 16(3), 291-302. https://doi.org/10.1002/jtr.1929

Park, J.Y., \& Jang, S.C.S. (2013). Confused by too many choices? Choice overload in tourism. Tourism Management, 35, 1-12. https://doi.org/10.1016/j.tourman.2012.05.004

Pesonen, J.A. (2015). Targeting Rural Tourists in the Internet: Comparing Travel Motivation and Activity-Based Segments. Journal of Travel \& Tourism Marketing, 32(3), 211-226. https://doi.org/1 0.1080/10548408.2014.895695

Rodzi, N.I., Zaki, S.A., \& Subli, S.M. (2013). Between Tourism and Intangible Cultural Heritage. Procedia - Social and Behavioral Sciences, 85, 411-420. https://doi.org/10.1016/j.sbspro.2013.08.370

Sarmento, M., Simões, C., \& Farhangmehr, M. (2015). Applying a relationship marketing perspective to B2B trade fairs: The role of socialization episodes. Industrial Marketing Management, 44, 131-141. https://doi.org/10.1016/j.indmarman.2014.10.010

Saxena, G., Clark, G., Oliver, T., \& Ilbery, B. (2007). Conceptualizing Integrated Rural Tourism. Tourism Geographies, 9(4), 347-370. https://doi.org/ $10.1080 / 14616680701647527$

Sharpley, R., \& Forster, G. (2003). The implications of hotel employee attitudes for the development of quality tourism: The case of Cyprus. Tourism Management, 24(6), 687-697. https://doi.org/10.1016/s0261-5177(03)00044-x

Sidali, K.L., \& Schulze, B. (2010). Current and future trends in consumers' preference for farm tourism in Germany. Leisure/Loisir, 34(2), 207-222. https://doi.org/10.1080/14927713.2010.481116

Sidali, K.L., Kastenholz, E., \& Bianchi, R. (2018). Food tourism, niche markets and products in rural tourism: Combining the intimacy model and the experience economy as a rural development strategy. Rural Tourism, 47-65. https://doi.org/10.4324/9781315111865-3

Sims, R. (2009). Food, place and authenticity: Local food and the sustainable tourism experience. Journal of Sustainable Tourism, 17(3), 321-336. https://doi.org/10.1080/09669580802359293

Sims, R. (2010). Putting place on the menu: The negotiation of locality in UK food tourism, from production to consumption. Journal of Rural Studies, 26(2), 105-115. https://doi.org/10.1016/j.jrurstud.2009.09.003

Smith, A., \& MacKinnon, J.B. (2008). Plenty: Eating locally on the 100-mile diet. New York: Three Rivers Press.

Soper, K. (2007). Re-thinking the 'Good Life'. Journal of Consumer Culture, 7(2), 205-229. https://doi.org/10.1177/1469540507077681

Sotiriadis, M.D., \& Zyl, C.V. (2013). Electronic word-of-mouth and online reviews in tourism services: The use of twitter by tourists. Electronic Commerce Research, 13(1), 103-124. https://doi.org/10.1007/s10660-013-9108-1

Sánchez, J., Callarisa, L., Rodríguez, R.M., \& Moliner, M.A. (2006). Perceived value of the purchase of a tourism product. Tourism Management, 27(3), 394409. https://doi.org/10.1016/j.tourman.2004.11.007

Tan, G.W., Lee, V.H., Lin, B., \& Ooi, K. (2017). Mobile applications in tourism: The future of the tourism industry? Industrial Management \& Data Systems, 117(3), 560-581. https://doi.org/10.1108/imds-12-2015-0490

Tarlow, P.E. (2014). Tourism security: Strategies for effectively managing travel risk and safety. Amsterdam: Butterworth-Heinemann, Elsevier.

Thurlow, C., \& Jaworski, A. (2012). Elite mobilities: The semiotic landscapes of luxury and privilege. Social Semiotics, 22(4), 487-516. https://doi.org/10.1080/10350330.2012.721592

Torres, R. (2002). Toward a better understanding of tourism and agriculture linkages in the Yucatan: Tourist food consumption and preferences. Tourism Geographies, 4(3), 282-306. https://doi.org/10.1080/14616680210147436

Törőcsik, M. (2011). Fogyasztói magatartás: Insight, trendek, vásárlók. [Consumer behaviour: Insight trends, customers]. Budapest. Akadémiai Kiadó.

Töröcsik, M. (2014). Az ételfogyasztás megatrend kapcsolódásai. [The megatrend connections of food consumption] Táplálkozásmarketing, 1(1-2), 19-27. https://doi.org/10.20494/tm/1/1-2/2

Tsaur, S., \& Lin, Y. (2004). Promoting service quality in tourist hotels: The role of HRM practices and service behavior. Tourism Management, 25(4), 471481. https://doi.org/10.1016/s0261-5177(03)00117-1

Turner, L.W., \& Witt, S.F. (2001). Factors Influencing Demand for International Tourism: Tourism Demand Analysis Using Structural Equation Modelling, Revisited. Tourism Economics, 7(1), 21-38. https://doi.org/10.5367/000000001101297711

Wenzel, E., Kirig, A., \& Rauch, C. (2007). Zielgruppe LOHAS wie der grüne Lifestyle die Märkte erobert. Kelkheim: Zukunftsinst.

Woodland, M., \& Acott, T. (2007). Sustainability and Local Tourism Branding in England's South Downs. Journal of Sustainable Tourism, 15(6), 715-734. https://doi.org/10.2167/jost652.0

Zou, T., Huang, S.S., \& Ding, P. (2012). Toward A Community-driven Development Model of Rural Tourism: The Chinese Experience. International Journal of Tourism Research, 16(3), 261-271. https://doi.org/10.1002/jtr.1925

*** Hungarian Central Statistical Office (2019) Summary tables (STADAT) - Time series of annual data - Tourism, catering, Downloaded: 2020. 11. 23. https://www.ksh.hu/stadat_annual_4_5 